\title{
Kewenangan Notaris Dalam Perjanjian Hak Asuh Atas Anak Akibat Perceraian
}

\author{
Ni Putu Noving Paramitha Pandy ${ }^{1}$, Ni Luh Gede Astariyani ${ }^{2}$ \\ ${ }^{1}$ Program Studi Magister (S2) Kenotariatan Fakultas Hukum Universitas Udayana, E-mail: \\ pandy.noving@yahoo.com \\ 2Fakultas Hukum Universitas Udayana, E-mail: luh_astariyani@unud.ac.id
}

\begin{tabular}{l}
\hline Info Artikel \\
\hline Masuk : 20 Januari 2020 \\
Diterima : 27 Mei 2020 \\
Terbit :31 Juli 2020 \\
Keywords : \\
Divorce; Children Care Right; \\
Agreement; Notary's \\
Authority. \\
\\
\\
Kata kunci: \\
Perceraian; Hak Asuh Anak; \\
Perjanjian; Kewenangan \\
Notaris. \\
\\
Corresponding Author: \\
Ni Putu Noving Paramitha \\
Pandy, E-mail: \\
pandy.noving@yahoo.com \\
DOI : \\
10.24843/AC.2020.v05.i02.p02 \\
\end{tabular}

\begin{abstract}
The purpose of this study is to find out and analyze the authority of a notary in making custody agreements on children, and to know and analyze the legal position of custody agreements on children, to court decisions related to divorce between the two biological parents of children. This type of research is normative research. The type of approach used is the statutory approach and conceptual approach. The legal material collection technique used is literature study. The results showed that the Notary has the authority to make authentic child custody agreements, and the authority of the Notary can have an impact on the divorce proceedings in the court running more efficiently in terms of child custody or the rights and obligations of parents after separation, because Notaries also play a role important as an intermediary and formulator of the desires of both parties (divorced couples).

Abstrak

Tujuan dari penelitian ini adalah untuk mengetahui dan menganalisis mengenai kewenangan notaris dalam pembuatan perjanjian hak asuh atas anak, dan mengetahui serta menganalisis mengenai kedudukan hukum dari perjanjian hak asuh atas anak, terhadap putusan pengadilan terkait perceraian antara kedua orang tua biologis anak. Jenis Penelitian tergolong penelitian normatif. Jenis Pendekatan yang dipergunakan ialah pendekatan perundang-undangan dan pendekatan konseptual. Teknik pengumpulan bahan hukum yang digunakan ialah studi kepustakaan. Hasil penelitian menunjukkan bahwa Notaris memiliki kewenangan sebagai pembuat perjanjian hak asuh anak yang otentik, serta kewenang Notaris tersebut dapat memberikan dampak pada proses persidangan perceraian di pengadilan berjalan lebih efisien dalam hal hak asuk anak ataupun hak serta kewajiban orang tuanya setelah berpisah, karena Notaris juga berperan penting sebagai penengah dan perumus keinginan kedua belah pihak (pasangan yang telah bercerai).
\end{abstract}




\section{Pendahuluan}

Perkawinan ialah keterikatan lahir-batin seseorang pria dan seseorang wanita, yang mana dianggap sakral dan diakui oleh Hukum, hal ini karena perkawinan dilaksanakan secara hukum dan secara agama. Maka biasanya perkawinan prosesinya dilangsungkan secara agama dilanjutkan kemudian pencatatan secara hukum. Sebagaimana dinyatakan dalam hasil penelitian Aziah Risma, adapun perkawinan pada dasarnya bertujuan demi terbentuknya keluarga saling membahagiakan serta abadi atas dasar Ketuhanan. ${ }^{1}$

Namun meskipun begitu, ketika terdapat permasalahan internalrumah tangga dianggap tak memungkinkan lagi diselesaikan dan perkawinan tersebut takkan dapat dipertahankan lagi, maka dapat menyebabkan perkawinan tersebut berujung pada perceraian. Dalam proses perceraian (lepasnya ikatan perkawinan) tersebut sama halnya dengan perkawinan, yang dilakukan secara agama dan hukum. Secara agama dapat diselesaikan menurut agama dari pasangan tersebut serta mengikuti adat istiadat pasangan tersebut, sedangkan secara hukum, proses perceraian hingga putusan perceraian dilaksanakan sesuai prosedur di pengadilan yang memiliki kekuatan dan kepastian hukum atas putusan perpisahan perkawinan tersebut. Lepasnya perkawinan karena perceraian dinyatakan pula didalam Pasal 38 Undang-Undang Nomor 16 tahun 2019 tentang Perubahan Atas Undang-Undang Nomor 1 Tahun 1974 Tentang Perkawinan (selanjutnya disebut UU Perkawinan). Kemudian dampak dari lepasnya keterikatan perkawinan berupa perceraian sebagaimana ditentukan pada UU Perkawinan, pada prinsipnya yakni menyatakan dan mengatur bahwa bapak atau ibu berkewajiban bahkan diharuskan dalam pemeliharaan serta mendidik buah hatinya untuk kepentingan buah hatinya itu sendiri. Ketentuan ini berlaku jika dalam perkawinan tersebut telah melahirkan buah hati, dapat dikatakan bahwa yang paling merasakan dampak dari perpisahan pasangan tersebut ialah anak mereka. Berpisahnya orang tua si anak akan berdampak pada banyak hal, seperti emosional anak terutama terkait hak pengasuhan anak tersebut yang kini tidak lagi diasuh oleh kedua orang tuanya secara utuh dalam satu atap.

Putusan pengadilan memang sebagai salah satu dasar untuk salah satu pihak mendapatkan atau menerima hak asuh atas anaknya, akan tetapi terkadang masih terdapat konflik untuk memperebutkan hak mengasuh anak tersebut sebelum atau bahkan setelah adanya putusan hakim. Selain terkait konflik yang timbul terkait perebutan hak asuh anak, terdapat pula pengingkaran atas apa yang telah diputuskan oleh hakim saat memutuskan hak asuh. Anak akan lebih menjadi korban atas perpisahan orang tuanya dan konflik yang timbul terkait hak asuh atas dirinya.

Namun saat ini terdapat beberapa solusi agar meminimalisir munculnya konflik perebutan hak asuh anak atau ingkar atas kewajiban orang tua yang telah berpisah tersebut, yakni dengan membuat perjanjian hak asuh anak yang khususnya membuat perjanjian tersebut dihadapan dan disahkan oleh notaris.

Perjanjian ini akan berisikan keinginan serta kesepakatan dari orang tua yang berpisah, sehingga nantinya akan dapat adil bagi kedua belah pihak baik ayah ataupun ibu.

${ }^{1}$ Rohadi, N.,\& Setiyanjaya, A. R. J. D.,(2014-2015). Pertimbangan Hakim Dalam Memutus Perkara Hak Asuh Anak Akibat Terjadinya Perceraian (Studi Kasus Putusan Nomor: 0536/pdt.g/2012/pa.ska.). Serambi Hukum 8(02) 46-60. 
Beberapa hal yang terkait yakni mengenai perhatian, pembiayaan dalam bersekolah serta rumah yang ditempati oleh buah hatinya harus tetap dapat terpenuhi meski orang tua telah memutuskan untuk berpisah. ${ }^{2}$ Meskipun pembuatan perjanjian hak asuh anak akibat perceraian yang dibuat sebelum putusan pengadilan dianggap dapat meminimalisir konflik akan tetapi perlu diperhatikan beberapa hal yang mana diangkat menjadi perumusan permasalah yang akan dibahas, yakni :

1. Bagaimanakah kewenangan notaris dalam membuat perjanjian hak asuh anak?

2. Bagaimanakah akibat hukum Atas Perjanjian Hak Asuh Anak Akibat Perceraian ?

Melalui penelitian ini diharapkan dapat terjawab kekritisan terkait hal-hal tersebut.

Kemudian adapun tujuan umum diangkatnya isu ini ialah untuk memancing kekritisan pola pikir pembaca dan dapat menjadi salah satu solusi yang dipergunakan apabila terdapat kondisi terkait hak asuh akibat perceraian. Kemudian tujuan khususnya ialah untuk mengetahui kewenangan notaris dalam perjanjian hak asuh anak serta akibat hukum dari perjanjian tersebut.

Sebagaimana disampaikan pada tujuan penulisan ini untuk memicu kekritisan pembaca juga untuk memperkaya ilmu dan masukan terhadap penelitian terkait yang pernah ada sebelumnya, yakni penelitian yang dibuat oleh Veronica Dini Krissanti, dalam penelitiannya yang berjudul "Kedudukan Pemegang Hak Asuh Anak Akibat Dari Perceraian Dan Kewenangan Notaris Dalam Pembuatan Akta Perjanjian Hak Asuh Anak (Studi Perbandingan Hukum Indonesia Dan Belanda)". 3 Pada prinsipnya, penelitian ini lebih berfokus atas pengaturan hak mengasuh anak pada UU Perkawinan di Indonesia dan di Belanda, maka pokok pembahasan atau rumusan masalah yang diangkat tidaklah sama. Kemudian juga penelitian dari Ariyawati, penelitiannya yang berjudul "Peranan Notaris Terhadap Perjanjian Hak Pengasuhan Anak Sebagai Akibat Perceraian".4 Yang mana lebih membahas pada akta Notaris yang otentik akan mempermudah hakim memutuskan hak asuh, kemudian penelitian tersebut juga lebih membahas kedudukan anak akibat perceraian. Kedua penelitian sebelumnya memiliki persamaan pada pokoknya terkait Perjanjian Hak Asuh Anak Akibat Perceraian yang dilahirkan oleh Notaris, akan tetapi dalam Penelitian ini akan menunjukkan bahwa Notaris yang berwenang sebagai pejabat pembuat segala perjanjian yang otentik dapat membantu proses sidang perceraian lebih efisien secara waktu danlangsung diketahui keinginan para pihak (orang tua yang bercerai).

\section{Metode Penelitian}

Penelitian hukum sebagaimana dijabarkan oleh Prof. Abdulkadir Muhammad, terdiri dari Penelitian hukum yang normatif, Penelitian hukum yang normatif-empiris,

\footnotetext{
${ }^{2}$ Tektona, R. I. (2012). Kepastian hukum terhadap perlindungan hak anak korban perceraian. Muwâazâh, 4(1), h.21-29.

${ }^{3}$ Krissanti, V. D. (2019). Kedudukan pemegang hak asuh anak akibat dari perceraian dan kewenangan notaris dalam pembuatan akta perjanjian hak asuh anak (studi perbandingan hukum Indonesia dan Belanda) (Doctoral dissertation, Universitas Pelita Harapan).

4 ARIYAWATI, S., \& Marsudi Triatmodjo, S. H. (2008). Peranan notaris terhadap perjanjian hak pengasuhan anak sebagai akibat perceraian (Doctoral dissertation, Universitas Gadjah Mada).
} 
Penelitian empiris, pembagian ini bergantung pada fokus penelitian itu sendiri. ${ }^{5}$ Penelitian ini dikategorikan penelitian normatif, yang mana melalui penelitian ini menggambarkan kewenangan Notaris berdasarkan Undang-Undang Nomor 2 Tahun 2014 tentang Perubahan atas Undang-Undang Nomor 30 Tahun 2004 tentang Jabatan Notaris (selanjutnya disebut UU Jabatan Notaris) dalam membuat perjanjian autentik beserta mempunyai akibat hukum yang mana pada penelitian ini berdampak pengikatan seluruh pihak yang membuat dan menyetujui perikatan itu sendiri, khususnya pasangan yang berpisah (orang tua anak yang akan ditentukan hak asuhnya) serta kemanfaatan dari produk Notaris yang berupa perjanjian hak asuh anak tersebut dimasyarakat khususnya dalam pembuatan perjanjian hak asuh anak dalam keadaan orang tua berpisah secara hukum syang tetap pada melihat pada aspek hukum positif terkait hak asuh anak serta kewenangan Notaris. Serta menilik pula pada

Metode pendekatan yang dipergunakan merupakan Metode Perundang-Undangan (statue approach) yang mana penggunaan pendekatan perundang-undangan yangmana menilik pada peraturan terkait kewenangan Notaris, perlindungan anak serta perceraian.

Kemudian sumber bahan hukum, yakni menggunakan bahan terdiri dari hukum primer serta juga sekunder, bahan hukum primer yang mempergunakan, yakni UndangUndang Dasar Negara Republik Indonesia Tahun 1994, Undang-Undang Nomor 16 tahun 2019 tentang Perubahan Atas Undang-Undang Nomor 1 Tahun 1974 Tentang Perkawinan, Undang-Undang Nomor 2 Tahun 2014 Tentang Perubahan Atas UndangUndang Nomor 30 tahun 2004 tentang Jabatan Notaris, dan Undang-Undang Nomor 35 Tahun 2014 tentang Perubahan Atas Undang-Undang Nomor 23 Tahun 2002 Tentang Perlindungan Anak, sedangkan bahan hukum sekunder yangmana kombinasi jurnal beserta juga pustaka-pustaka yang mempunyai keterkaitan dengan penelitian. Pola penghimpunan materi hukum didalam penelitian ialah dilaksanakannya penghimpunan dokumen, melalui mekanisme membaca disertakan dengan mempelajari bahan bacaan yang terkait. Mengenai metode penganalisisan bahan hukum yakni dengan teknik yang deskriptif, yang mana penelitian ini akan menguraikan keadaan terkait perjanjian hak asuh anak dari sudut yuridis.

\section{Hasil Dan Pembahasan}

\subsection{Kewenangan Notaris Atas Perjanjian Hak Asuh Anak Akibat Perceraian}

Sebelum membahas mengenai kewenangan Notaris mengenai perjanjian hak asuh anak tersebut, perlu diketahui makna dari kewenangan, perjanjian, serta hak asuh itu sendiri. Terkait kewenangan sebagaiman dinyatakan dalam Kamus Besar Bahasa Indonesia online pada prinsipnya, yakni sebagai hak serta kekuasaan atas melaksanakan sesuatu. ${ }^{6}$ Kemudian perjanjian sebagaimana dinyatakan dalam Kitab Undang-Undang Hukum Perdata, pada prinsipnya merupakan suatu perbuatan yang mana seorang atau lebih memautkankan diri pada seorang lain atau lebih. Secara mudah untuk dipahami, digambarkan bahwa perjanjian tersebut adanya dua pihak yang mengikat diri dengan sengaja dan sadar. Makna terkait hak asuh yakni didasarkan pada Undang-Undang

\footnotetext{
${ }^{5}$ Abdulkadir Muhammad.(2004). Hukum Dan Penelitian Hukum, Cetakan 1. Bandung. PT Citra Aditya Bakti. h. 52

${ }^{6}$ https:// kbbi.kemdikbud.go.id/entri/kewenangan, diakses pada tanggal 12 April 2020
} 
Nomor 23 Tahun 2002 tentang Perlindungan Anak yang sudah mengalami perubahan menjadi Undang-Undang Nomor 35 Tahun 2014 tentang Perubahan Atas UndangUndang Nomor 23 Tahun 2002 tentang Perlindungan Anak, lantas berubah kembali yakni Peraturan Pemerintah Pengganti Undang-Undang Nomor 1 Tahun 2016 tentang Perubahan Kedua Atas Undang-Undang Nomor 23 Tahun 2002 tentang Perlindungan Anak, yangmana dilakukan penetapan Undang-Undang Nomor 17 Tahun 2016 tentang Penetapan Peraturan Pemerintah Pengganti Undang-Undang Nomor 1 Tahun 2016 tentang Perubahan Kedua Atas Undang-Undang Nomor 23 Tahun 2002 tentang Perlindungan Anak, pada prinsipnya dinyatakan terkait hak pengasuhan atau kuasa mengasuh merupakan kekuasaan orangtua dalam mengasu, mendidik, melakukan pemeliharaan, melindungi serta mengembangkan anak berdasarkan ajaran agama dianut olehnya serta kemampuan minat beserta bakat buah hati.

Setelah masuk pada pemahaman makna, maka kini pada penjelasan mendalam terkait kewenangan yang diperoleh Notaris. Adapun kewenangan yang diperoleh oleh seseorang Notaris seyogyanya kewenangan secara atributif, nang mana maknanya Notaris memperoleh atau berkewenangan atas dasar undang-undang yang berlaku. ${ }^{7}$ Kewenangan yang diperoleh oleh Notaris laksana pejabat umum yang melahirkan Akta merupakan kewenangan yang diperoleh langsung melalui yuridis (undang-undang), yakni UU Jabatan Notaris, terkhusus pada Pasal 15 ayat (1) serta tiada ikatan dengan pemerintah dalam pelaksanaan kewenangan dan perannya. ${ }^{8}$

Dapat dikatakan kewenangan Notaris atas perjanjian hak asuh anak akibat perceraian tersebut yakni sebagai pejabat pembuat perjanjian atau akta yang otentik serta dalam situasi ini pula sebagai mediator. Sebagai mediator ini ialah lebih kepada Notaris berperan dalam perumusan keinginan bagi pasangan yang akan berpisah serta pengesahan berupa tanda tangan diatas materai dalam perjanjian tersebut menjadi perjanjian yang sifatnya otentik dan mengikat pasangan yang berpisah (bercerai)tersebut.

Perjanjian hak asuh anak akibat perceraian pada dasarnya terkait tanggung jawab tetap dipikul kedua orang tua meskipun telah berpisah atau bahkan telah menjalin perkawinan kembali bersama pasangan lain, hal ini sangat erat keterkaitannya dengan HAM yang dimiliki buah hatinya sejak lahir, serta hukum perlindungan anak bagi buah hati mereka.

Sebagaimana ditentukan dalam Pasal 28B ayat(2) UUD RI tahun 1945, yakni"Setiap anak berhak atas kelangsungan hidup, tumbuh, dan berkembang serta berhak atas perlindungan dari kekerasan dan diskriminasi". Bersama ketetapan dalam Pasal 1 Ayat (12) UU Perlindungan Anak menyatakan yakni, "Hak anak adalah bagian dari hak asasi manusia yang wajib dijamin, dilindungi, dan dipenuhi oleh Orang Tua, Keluarga, masyarakat, Negara, pemerintah dan pemerintah daerah".

Selain itu menilik kembali pada pemahaman hak asuh atau kuasa asuh seyogyanya diatur di Pasal 1 angka (11) UU Perlindungan Anak yang disampaikan sebelumnya, pada prinsipnya merupakan kekuasaan bagi orangtua dalam hal mengasih, mendidik,

\footnotetext{
7 Rahman, M. D. F., (2014),"Kewenangan, Kewajiban Notaris dan Calon Notaris dalam Membuat Akta Autentik,". Kumpulan Jurnal Mahasiswa Fakultas Hukum 1, no.1, h.16-37.

8 Habib Adjie, (2011), Hukum Notaris Indonesia (Tafsir Tematik Terhadap UU No.30 Tahun 2004 Tentang Jabatan Notaris). Refika Aditama, Bandung, h.78.
} 
melindungi serta mengembangkan anak berdasarkan agama serta bakat minatnya ${ }^{9}$, menjadi dasar kuat bahwa hak asuh merupakan jalan agar anak tetap mendapatkan hak nya, maka hak asuh harus dilakukan dengan pertimbangan-pertimbangan demi kebaikan si buah hati.

Maka berdasarkan pada ketentuan-ketentuan peraturan hukum tersebut, sudah sepantasnya buah hati yang merasakan perpisahan orang tuanya harus tetap merasakan apa yang menjadi haknya sebagai seorang anak dari orang tuanya meskipun telah berpisah, terutama dalam pemenuhan kasih sayang dan kebutuhan secara meteriil terutama dalam pemenuhan sehari-hari dan biaya pendidikan.

Perjanjian hak asuh anak saat situasi atau keadaan rumah tangga mengalami perceraian dianggap sebagai salah satu solusi untuk mencegah adanya konflik dalam hal perebutan hak asuh anak atau sebaliknya terjadi saling lempar tanggung jawab, serta demi mempermudah hakim mengeksekusi hak asuh atas anak dan juga nantinya demi menghindari adanya wanprestasi atas keputusan pengadilan, dengan melakukan halhal diluar putusan hakim atas hak asuh anak, yang akan merugikan anak itu sendiri.

Sebagaimana disampaikan sebelumnya, maka disinilah akan sangat diperlukannya Notaris selaku pejabat umum berwenang menjadi mediator dan fasilitator bagi kedua pihak. Sebagai mediator dan fasilitator dalam merumus keinginan para pihak dan memformulasikan hingga terwujud kesepakatan kedua belah pihak berupa perjanjian yang dibubuhkan tanda tangan dihadapan para saksi serta disahkan oleh Notaris, kemudian peran sebagai penyuluh hukum terkait perjanjian secara umum dan khusus (perjanjian hak asuh anak), serta kekuatan dan akibat secara yuridis atas perjanjian yang Notaris buat dan/atau dihadapannya mengenai segala tanggung jawab, hak, kewajiban mereka bagi sang buah hati setelah terjadinya perceraian.

\subsection{Kedudukan Hukum Atas Perjanjian Hak Asuh Anak Akibat Perceraian}

Perjanjian sebagaimana disampaikan sebelumnya merupakan perbuatan dua pihak yang saling memiliki keterikatan diri secara sengaja dan sadar. Secara sadar itu sendiri diperkuat pada Pasal 1315 KUHPerdata yang singkat kata, menegaskan bahwa tiada serorangpun dapat melakukan ikatan diri atas nama dirinya ataupun memohon ditetapkan suatu perjanjian kecuali atas diri sendirinya. Apabila terdapatnya paksaan maka perjanjian akan batal didasarkan atas ketentuan dalam Pasal 1323 KUHPerdata. Adapun syarat-syarat yang perlu dipahami terlebih dahulu sebelum mengetahui kedudukan hukum atas suatu perjanjian khususnya dalam penelitian ini terkait perjanjian hak asuh anak, yakni yangmana diatur dalam Pasal 1320 KUHPerdata ${ }^{10}$, bagi keabsahan suatu perjanjian-perjanjian diwajibkan beberapa ketentuan, yakni :

1) Sepakat mereka yang mengikatkan dirinya;

2) Kecakapan untuk membuat suatu perikatan;

3) Suatu hal tertentu;

4) Suatu sebab yang halal.

9 Oelangan, M. D. (2016). Hak Asuh Anak Akibat Perceraian (Studi Perkara Nomor 0679/Pdt. G/2014/PA TnK). Pranata Hukum, 11(1). h.64

10 Ahmad Miru dan Sakka Pati, (2012), Hukum Perikatan Penjelasan Makna Pasal 1233 sampai 1456 BW. Rajawali Pers, Jakarta, h.63 
Makna dari pasal yang disampaikan merupakan penjelasan terait prasyarat yang wajib untuk terpenuhi agar dapat terwujudnya perjanjian, baik terkait pihak yang membuat perjanjian ataupun hal yang diperjanjikan. Wajib untuk adanya kesepakatan antara para pihak berupa keseuaian keinginan pihak yang melakukan perjanjian atas isi perjanjian. Kecakapan merupakan suatu syarat bahwa pihak yang melakukan perjanjian yang mana perjnajian merupakan perbuatan hukum telah mencapai umur 21 atau telah menikah (untuk yang kurang dari 21 tahun), kemudian terkait perceraian apabila belim mencapai 21 tahun tetap dianggap cakap karena telah melakukan perkawinan dan perceraian sebelum 21 tahun. Terkait hal tertentu yakni wajib untuk adanya objek yang diperjanjikan secara jelas dan mampu dipahami. Kemudian syarat terakhir mengenai sebab yang halal, tentu terkait perjanjian atas objek tersebut tidak menentang undangundang serta norma-norma yang telah ada, baik kesusilaan atau ketertiban umum.

Terkait dengan penelitian ini, pemahaman terkait Perceraian yangmana dinyatakan ekplisit oleh UU Perkawinan pada prinsipnya merupakan satu bentuk lepasnya ikatan perkawinan tersebut, serta untuk dapat terlaksananya perceraian terdapat segenap alibi yang diwajibkan dalam undang-undang tersebut. Perceraian tak hanya berdampak pada putusnya ikatan perkawinan, akan tetapi juga dapaknya dirasakan oleh anak dalam perkawinan tersebut.

Pada prinsipnya yang mana diwajiban dalam Pasal 41 UU Perkawinan, ayah dan/atau ibu tetap harus dan bertanggung jawab atas anak secara keseluruhan sebagaimana pula diputusnkan dalam Pengadilan, pasal tersebut menunjukan bahwa orang tua memiliki kewajiban dalam memberikan perlindungan serta menjamin bahwa terpenuhinya kebutuhan buah hatinya. Dari hasil wawancara Kompasiana.Com dengan Staf Pelayanan Hukum Lembaga Bantuan Hukum Asosiasi Perempuan Untuk Keadilan Jakarta, yakni pada prinsipnya ketika terjadi perceraian dalam UU Perkawinan (baik dalam kompilasi hukum islam ataupun hukum sipil), terkait hak asuh anak dibawah umur 12 tahun diserahkan kepada ibunya, kecuali jikala terjadi situasi sang Ibu berperilaku tidak baik dan lain-lainnya. ${ }^{11}$ Terkait hak yang dikecualikan ini berpegangan pada fakta yang cukup banyak terjadi, yang mana hak mengasuh anak tidak secara langsung jatuh dan diberikan pada sangibu (untuk anak dibawah umur pun dapat terjadi), dikarenakan beberapa keadaan menunjukkan putusan pengadilan oleh Yang Mulia Hakim melimpahkan hak asuh kepada pihak bapak, berbagai dasar pertimbangannya yakni sangibu tidak mampu secara fisik dan mental, kemudian juga dapat secara kemampuan yang kurang intelek dan teliti (hingga tahap membahayakan anak) serta pula faktor kedekatan emosional anak lebih condong dengan bapaknya. Kedudukan istri juga dapat sama dengan suami apabila istri lebih dominan dan mengprioritaskan pekerjaan dibandingkan anaknya, maka secara Hakim akan mempertimbangkan memberikan hak asuh kepada bapak demi kebahagiaan sang buah hati.

Terkadang hal seperti ini dapat menimbulkan konflik bila tidak disampaikan secara kekeluargaan dan didengarkan keinginan masing-masing pihak. Sebagaimana dinyatakan sebelumnya bahwa salah satu solusi bagi pasangan yang berpisah agar tidak melahirkan pertentangan terkait hak asuh anak ialah dengan membuat perjanjian hak asuh anak.

\footnotetext{
11https:// www.kompasiana.com/hidachilbeep/551ad916a33311e821b65ab3/hak-asuh-anakpasca-perceraian, diakses pada 18 Desember 2019
} 
Didasarkan pada Pasal ketentuan dalam Pasal 1313 KUHPerdata Terkait Perjanjian hak asuh anak akibat terjadinya perceraian ini merupakan perjanjian yang Notaris buat oleh dan/atau dihadapannya, demi bisa mengetahui kedudukan yuridis atas perjanjian tersebut perlu dilihat dari sudut pandang prinsip akan adanya perjanjian ialah adanya keinginan dan kesepakatan para pihak dalam hal ini orang tua yang berpisah secara hukum. Kemudian mengingat pula tujuan utama akan adanya perjanjian tersebut tentu untuk melindungi hak anak, sebagaimana hasil penelitian dari Fanani, A.Z, pada prinsipnya memaparkan bahwa kewajiban dari pasangan suami istri yang berpisah tersebut tetap ada dan tidak terputus bagi anaknya.12 Perumusan perjanjian hak asuh tidak semata-mata dari keinginan para pihak akan tetapi melihat dan mendengar keadaan serta masukkan keluarga yang dapat berperan sebagai saksi. Kemampuan secara materi tidak hanya menjadi tolok ukur, secara menyeluruh perlu diperhatikan dan dipertimbangkan untuk disepakati bersama.

Selain itu dari sudut lain perlu diperhatikan bahwa perjanjian tersebut dilahirkan oleh dan/atau dihapadan Notaris layaknya pejabat umum yang melahirkan akta autentik menjadikan perjanjian hak asuh yang Notaris buat oleh dan/atau dihadapannya tersebut memiliki kekuatan mengikat secara hukum kepada keseluruhan pihak yang menjalani perjanjian dalam pembahasan ini ialah pasangan yang berpisah, karena dengan diadakannya perjanjian tersebut akan memperjelas hubungan hukum dengan memperlancar jalan kepastian dan perlindungan bagi para pihak atas hal yang diperjanjikan dan memiliki kekuatan selama tidak adanya pembuktian terbalik, khususnya apabila perjanjian dibuat sebelum adanya keputusan hakim terkait kuasa mengasuh anak pasca terjadinya perceraian.

Perjanjian ini dapat dijadikan dasar pertimbangan oleh Hakim, karena pada prinsipnya sebagaimana dinyatakan dalam hasil penelitian Erisa Ardika Prasada, pertimbangan hakim merupakan titik penting dalam terlaksananya esensi dari putusan hakim yang adil serta memiliki kepastian hukum, serta adanya kemanfaatan bagi pihak terkait.13 Maka, disinilah kedudukan hukum dari perjanjian hak asuh anak akibat perceraian yang Notaris buat serta lahirkan oleh dan/atau dihadapannya, menurut praktis Penulis dapat menjadi pertimbangan bagi Hakim untuk memutuskan dan menetapkah kuasa mengasuh anak serta dapat menjadi alat pembuktian yang mengikat keseluruh pihak dapat patuh terhadap isi dari perjanjian yang telah disepakatkan,sehingga tujuan dibuatnya perjanjian tersebut akan terlaksana yakni demi kebaikan buah hatinya serta meminimalisir lahirnya konflik baru terkait hak asuh anak. Pada prinsipnya ketika terjadi kerenggangan hubungan perkawinan hingga dilakukan gugatan perceraian ke pengadilan, pasangan yang merupakan orangtua atas anak tersebut membuat perjanjian dihadapan Notaris dan disahkan oleh Notaris menjadi otentik dan akan berdampak pada mempercepat dan mempermudah proses perceraian dan memutuskan hak asuh atas anak tersebut.

\section{Kesimpulan}

12 Fanani, A. Z. (2017). Sengketa Hak Asuh Anak Dalam Hukum Keluarga Perspektif Keadilan Jender. Muslim Heritage, 2(1), 153-176.

${ }^{13}$ Prasada, E. A., \& Sapuan, A. (2017). Pertimbangan Hakim Dalam Menetapkan Hak Asuh Anak Akibat Perceraian Di Pengadilan Agama Kayuagung. Jurnal Hukum Uniski, 6(1), 34-46. 
Kewenangan Notaris atas perjanjian hak asuh anak akibat perceraian yakni sebagai pejabat umum yang menerima kewenangan atribusi dari UU Jabatan Notaris untuk memberikan penyuluhan hukum terkait perjanjian secara umum dan khusus terkait perjanjian hak asuh anak sesuai penelitian yang diangkat serta menjadi perumus keinginan pasangan yang berpisah tersebut mengenai tanggung jawab, kewajiban serta hak kepada anaknya pasca perceraian hingga terciptanya kesepakatan atas perjanjian yang sifatnya otentik dan mengikat kedua belah pihak. Kedudukan hukum atas perjanjian tersebut perlu didasarkan pada beberapa hal yakni dengan melihat perjanjian itu sendiri yang dimaknai bahwa dibuat didasarkan pada keinginan para pihak yang dicari titik tengah hingga lahirnya kesepakatan yang mengikat, kemudian Notaris membuatkan perjanjian dan/atau dihadapannya dan melakukan pengesahan atas perjanjian tersebut maka secara otomatis perjanjian tersebut telah memiliki kedudukan hukum sebagai perjanjian. Kemudian perjanjian otentik tersebut menjadi bahan pertimbangan Hakim untuk memutuskan hak kuasa mengasuh anak serta berdampak pada efisiensi waktu dan efektifitas proses persidangan.

\section{Daftar Pustaka \\ Buku}

Adjie, H. (2011). Hukum Notaris Indonesia (Tafsir Tematik Terhadap UU No.30 Tahun 2004 Tentang Jabatan Notaris). Refika Aditama: Bandung

Miru, A. dan Sakka Pati. (2012). Hukum Perikatan Penjelasan Makna Pasal 1233 sampai 1456 BW. Rajawali Pers: Jakarta

Muhammad, A. (2004). Hukum Dan Penelitian Hukum, Cetakan 1. PT Citra Aditya Bakti:

\section{Jurnal} Bandung

Fanani, A. Z. (2017). Sengketa Hak Asuh Anak Dalam Hukum Keluarga Perspektif Keadilan Jender. Muslim Heritage, 2(1)

Oelangan, M. D. (2016). Hak Asuh Anak Akibat Perceraian (Studi Perkara Nomor 0679/Pdt. G/2014/PA TnK). Pranata Hukum, 11(1).

Prasada, E. A., \& Sapuan, A. (2017). Pertimbangan Hakim Dalam Menetapkan Hak Asuh Anak Akibat Perceraian Di Pengadilan Agama Kayuagung. Jurnal Hukum Uniski, 6(1),

Rahman, M. D. F., (2014), Kewenangan, Kewajiban Notaris dan Calon Notaris dalam Membuat Akta Autentik. Kumpulan Jurnal Mahasiswa Fakultas Hukum 1, no.1

Rohadi, N.,\& Setiyanjaya, A. R. J. D.,(2014-2015). Pertimbangan Hakim Dalam Memutus Perkara Hak Asuh Anak Akibat Terjadinya Perceraian (Studi Kasus Putusan Nomor: 0536/pdt.g/2012/pa.ska.). Serambi Hukum 8(02)

Tektona, R. I. (2012). Kepastian hukum terhadap perlindungan hak anak korban perceraian. Muwâzâh, 4(1)

\section{Artikel}

https://kbbi.kemdikbud.go.id/entri/kewenangan, diakses pada tanggal 12 April 2020 https:// www.kompasiana.com/hidachilbeep/551ad916a33311e821b65ab3/hak-asuh-

\section{Disertasi} anak-pasca-perceraian, diakses pada 18 Desember 2019

Ariyawati, S., \& Marsudi Triatmodjo, S. H. (2008). Peranan notaris terhadap perjanjian hak pengasuhan anak sebagai akibat perceraian (Doctoral dissertation, Universitas Gadjah Mada) 


\section{Peraturan Hukum}

Undang-Undang Dasar Negara Republik Indonesia Tahun 1994

Undang-Undang Nomor 16 tahun 2019 tentang Perubahan Atas Undang-Undang Nomor 1 Tahun 1974 Tentang Perkawinan (Lembaran Negara Republik Indonesia Tahun 2019 Nomor 186, Tambahan Lembaran Negara Republik Indonesia Nomor 6401)

Undang-Undang Nomor 2 Tahun 2014 Tentang Perubahan Atas Undang-Undang Nomor 30 tahun 2004 tentang Jabatan Notaris (Lembaran Negara Republik Indonesia Tahun 2014 Nomor 3, Tambahan Lembaran Negara Republik Indonesia Nomor 5491)

Undang-Undang Nomor 35 Tahun 2014 tentang Perubahan Atas Undang-Undang Nomor 23 Tahun 2002 Tentang Perlindungan Anak (Lembaran Negara Republik Indonesia Tahun 2014 Nomor 297, Tambahan Lembaran Negara Republik Indonesia Nomor 5606) 